\title{
A comparison study of regional atmospheric simulations with an elastic backscattering Lidar and sunphotometry in an urban area
}

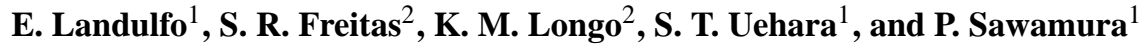 \\ ${ }^{1}$ Instituto de Pesquisas Energéticas e Nucleares - IPEN, São Paulo, Brazil \\ ${ }^{2}$ Centro de Previsão do Tempos e Estudos Climáticos - CPTEC, Cachoeira Paulista, Brazil \\ Received: 7 May 2008 - Published in Atmos. Chem. Phys. Discuss.: 7 April 2009 \\ Revised: 27 August 2009 - Accepted: 27 August 2009 - Published: 18 September 2009
}

\begin{abstract}
We describe a comparison study of Aerosol Optical Thickness (AOT) from numerical simulations using a regional atmospheric model with an elastic backscattering lidar operating at $532 \mathrm{~nm}$ and a sunphotometer belonging to the AERONET network at São Paulo $\left(23^{\circ} \mathrm{S} 46^{\circ} \mathrm{W}\right)$ city, Brazil, a very populated urban area. The atmospheric model includes an aerosol emission, transport and deposition module coupled to a radiative transfer parameterization, which takes the interaction between aerosol particles and short and long wave radiation into account. A period of one week was taken as case study during the dry season (late August) when intense biomass burning activities occur at remote areas in South America, and meteorological conditions disfavor the pollution dispersion in the city of São Paulo. The situation presented here showed how smoke from biomass burning in remote areas is transported to the south-east part of Brazil and affects the optical atmospheric conditions in São Paulo. The numerical simulations are corroborated by in situ measurements of AOT obtained by lidar and sun photometry.
\end{abstract}

\section{Introduction}

In South America every year during the dry season (July to October) a continental scale biomass burning activity (vegetation fires) occurs mainly associated to land use change. A few weeks after the burning season started, large areas of South America (SA) were covered by dense smoke plumes of aerosol particles and several types of primary and secondary

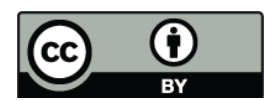

Correspondence to: E. Landulfo (landulfo@gmail.com) gases. In GOES-8 visible imagery (Prins et al., 1995) an extense regional smoke plume was observed covering an area of approximately 4 to 5 million $\mathrm{km}^{2}$ during the biomass-burning season of 2005. Freitas et al. (2009) described a conceptual model of how the typical South American synoptic systems drive the transport of biomass burning emissions. The general picture is dominated by an anticyclone associated with the South Atlantic Subtropical High (SASH) centered on the Atlantic Ocean and an orographic barrier of the Andes Mountains at West. The smoke mostly produced in the Amazon basin and Central part of Brazil is then normally carried out to West and then turned to Southwest following the East side of Andes. In same cases, this transport is strongly augmented by occurrence of the South America Low Level Jet, a strong low troposphere pole-ward stream at East side of the Andes (Vera et al., 2006; Longo et al., 2006a,b). However the occurrence of other transient systems like mid-latitude cold fronts from the South can change this scenario and prepares corridors of smoke export towards the south-east part of Brazil, where the most populated urban areas do exist. In these events, the local air pollution produced by the urban activities gain additional load of pyrogenic and aged aerosols and gases, changing the local air quality and atmospheric optical property patterns. In this paper we study the aerosol transport which can reach areas about $2000 \mathrm{~km}$ away from the sources (Freitas et al., 2005) and and even affect lower tropospheric aerosol levels in a densely populated area such as São Paulo. A backscattering LIDAR system located at the outskirts of São Paulo was setup since 2001 and has been operational since then (Landulfo et al., 2003). With this system one can vertically profile the aerosol in the atmosphere and retrieve its optical properties. During the so called dry season which corresponds to the period of June through September

Published by Copernicus Publications on behalf of the European Geosciences Union. 
the number of aerosol transport events into the Metropoli$\tan$ Area of São Paulo increases drastically. In this case one expects to observe aerosol layers above the Planetary Boundary Layer (PBL) where less mixing with local sources happen. In order to corroborate these transports we correlated the aerosol layers above the PBL and their optical properties with a regional forecasted calculated model capable of evaluating the concentration of biomass burning products such as: Carbon Monoxide (CO), Particulate Material with a size below $2.5 \mu \mathrm{m}\left(\mathrm{PM}_{2.5}\right)$, and meteorological quantities such as temperature, pressure, wind field, etc. In this paper the period of 24 August through 30 August was chosen as a case study for a model validation with a colocated AERONET sunphotometer (SunP) and the LIDAR system (LS). After the selection of these periods a day by day analysis was carried out to obtain: the Ångström Exponent(AE), the Aerosol Optical Thickness (AOT), the Extinction-to-Backcatter Ratio (LR) and a synoptic analysis of the time period considered.

\section{Model and numerical simulations description}

The numerical simulation described here was performed by using the Coupled Aerosol and Tracer Transport model to the Brazilian developments on the Regional Atmospheric Modeling System (CATT-BRAMS, Freitas et al., 2005; Longo et al., 2007). Shortly, CATT is an "on-line" transport model fully coupled to the Regional Atmospheric Modeling System (RAMS, Walko et al., 2000) and has been designed to study emission, deposition and transport of gases and aerosols associated with biomass burning in South America. An important characteristic of this modeling system is that the biomass burning emission source is based on the fire counts daily observed by remote sensing techniques (Freitas et al., 2005; Longo et al., 2007), allowing realistic spatial and temporal injection of smoke from fires in the simulated atmosphere. Additionally, CATT-BRAMS includes a radiation scheme that takes into account the interaction between aerosol particles and short and long wave radiation. The consistent description of the smoke and its interaction with short- and long-wave radiation make the CATT-BRAMS model reliable for atmospheric feedback studies of the smoke aerosols (Longo et al., 2006b). Model simulations for the 2005 dry season were performed using 2 grids: the coarse grid with $160 \mathrm{~km}$ horizontal resolution covering the South American (SA) and African continents and the nested finer grid with a horizontal resolution of $40 \mathrm{~km}$, covering only SA. The vertical resolution for both grids varies telescopically with higher resolution at the surface $(150 \mathrm{~m})$ with ratio of 1.07 up to a maximum vertical resolution of $850 \mathrm{~m}$, with the top of the model at $23 \mathrm{~km}$ (a total of 42 vertical levels). The soil model is composed of 7 layers with variable resolution, distributed within the first $4 \mathrm{~m}$ of soil depth. For the atmospheric initial and boundary conditions, the 6 hourly Brazilian Center for Weather Forecast and Climate Studies (CPTEC) T126 analysis field was used for the model initialization and to provide the necessary boundary condition using the traditional RAMS scheme, the 4DDA (four-dimensional data assimilation) technique. Initial soil moisture was taken from the (Gevaerd and Freitas, 2006) estimation technique. The soil temperature was initialized assuming a vertically homogenously field defined by the air temperature closest to the surface from the atmospheric initial data. The biomass burning source emission was defined from remote sensing fire counts, as described below. The fire database used a combination of the Geostationary Operational Environmental Satellite - Wildfire Automated Biomass Burning Algorithm (GOES WF_ABBA product (cimss.ssec.wisc.edu/goes/burn/ wfabba.html; Prins et al., 1995), the Brazilian National Institute for Space Research fire product, which is based on the Advanced Very High Resolution Radiometer (AVHRR), aboard the NOAA polar orbiting satellites series (www.cptec. inpe.br/queimadas; Setzer and Pereira, 1991) and the Moderate Resolution Imaging Spectroradiometer (MODIS) fire product (modis-fire.umd.edu; Giglio et al., 2003). The fire counts were then processed by the emission model and daily emission sources were obtained for $\mathrm{CO}$ and $\mathrm{PM}_{2.5}$. During simulation, the emission data is daily ingested in the model to provide the tracer fluxes. Once emitted to the atmosphere, $\mathrm{CO}$ and $\mathrm{PM}_{2.5}$ are dispersed and transported by the wind in the model providing an useful tool to simulate and forecast its concentration and trends.

\section{Experimental setup}

\subsection{Lidar apparatus}

A ground-based elastic Lidar system has been operational in São Paulo since 2001 at the Laboratory of Environmental Laser Applications at the Centre for Laser and Applications (CLA/IPEN) Landulfo et al. (2003, 2005). This coaxial lidar system is a single-wavelength backscatter system pointing vertically to the zenith. The light source used is a commercial Nd:YAG laser (Brilliant by Quantel SA) operating at the second harmonic frequency (SHF), namely at $532 \mathrm{~nm}$, with a fixed repetition rate of $20 \mathrm{~Hz}$. The average emitted power can be selected up to values as high as $3.3 \mathrm{~W}$ and peak-power of a few MW when the pulse duration is taken into account (around $4 \mathrm{~ns}$ ). The beam divergence is typically about $0.5 \mathrm{mrad}$ at $85 \%$ (2 sigma-level) of energy. As a light collector we employ a newtonian telescope with a primary mirror with $30 \mathrm{~cm}$ of diameter and focal length $f=30 \mathrm{~cm}$. The telescope's field of view is variable ranging from 0.5 to $5 \mathrm{mrad}$ by using a small diaphragm. At the present configuration the system has a maximum overlap beggining at $300 \mathrm{~m}$ allowing the system to perform up to $8-10 \mathrm{~km}$ during daytime (15-25 km nighttime). The backscattered laser radiation is detected by a low-noise photomultiplier coupled to a $1 \mathrm{~nm}$ FWHM interference filter to assure the reduction of 
solar background and improve the signal-to-noise ratio. The PMT output signal is recorded by a transient recorder in both analog and photoncounting modes. Data are averaged every 2 min and summed up in blocks corresponding to about $30 \mathrm{~min}$. The raw spatial resolution applied is $15 \mathrm{~m}$, which corresponds to $100 \mathrm{~ns}$ sampling in time.

\subsection{Aeronet sunphotometer}

The sunphotometer (CIMEL 318A) located at São Paulo is in close range to the Lidar station. This system belongs to the AERONET network (Holben et al., 1998) and performs aureole and sky radiances measurements in order to retrieve the Aerosol Optical Thickness for aerosols at several wavelengths. The standard measurements are taken in the whole spectral interval, and their number depends on the daytime duration. Besides the AOT, it is possible to obtain the aerosol size distribution, the phase function, single scattering albedo and extinction-to-backscatter ratio. The sunphotometer like the others in this network is periodically calibrated by a remote computer or locally. This procedure assures measurement accuracy to within 1-3\%. However various instruments, calibration, atmospheric, and methodological factors can influence the precision and accuracy achieved and the total uncertainty in the AOT might reach around 510\% (Dubovik et al., 2002).

\section{Lidar and aeronet data processing}

\subsection{Lidar data retrieval}

The retrieval of the aerosol optical properties is based on the measurements of the aerosol backscatter coefficient $\beta_{\text {aer }}$ at $532 \mathrm{~nm}$, up to an altitude of $5-6 \mathrm{~km}$. The vertical profile of the aerosol backscatter and extinction coefficients is obtained by the LIDAR inversion technique following an inversion algorithm Klett (1985). In general, the inversion profile is based on the solution of the so called LIDAR equation:

$$
\begin{aligned}
& P\left(\lambda_{L}, R\right)=P_{L}\left(\frac{c \tau}{2}\right) A_{o} \xi(\lambda) \zeta(R) R^{-2} \beta(\lambda, R) \\
& \times \exp \left[-2 \int_{0}^{R} \alpha(\lambda, r) d r\right]
\end{aligned}
$$

where, $P\left(\lambda_{L}, R\right)$ is the lidar signal received from a distance $R$ at the wavelength $\lambda, P_{L}$ is emitted laser power, $A_{o}$ is the telescope receiving area, $\xi(\lambda)$ is the received spectral transmission factor, $\beta(\lambda, R)$ is the atmospheric volume backscattering coefficient, $\zeta(R)$ is the overlap factor between the field-of-view of the telescope and the laser beam, $\alpha(\lambda, R)$ is the extinction coefficient, $c$ is the speed of light and $\tau$ is the laser pulse lenght. In Eq. 1, the $\alpha$ and $\beta$ coefficients can be separated into two sets, one for the molecular scattering and the other for the particle scattering component. Besides in the inversion technique applied here there is a reference altitude which is used as an upper limit where we consider an aerosol-free region. Besides in order to keep this inversion "well" behaved we have to assume a relation between $\alpha$ and $\beta$ known also a the Lidar ratio:

$S_{\text {aer }}=\frac{\alpha_{\text {aer }}}{\beta_{\text {aer }}}$

The Lidar ratio can be interpreted as the amount of light being absorbed or scattered out of the telescope FOV by the backscattered light due the influence of the aerosols, therefore it is a microphysical property of the aerosol which depends on the aerosol refractive index, size and shape of the aerosol particles. Since aerosols change their physicochemical properties due relative humidity changes and aging this will have a direct impact on their optical properties and therefore give a wide values of lidar ratio and their interpretation (Anderson et al., 2000; Ackermann, 1998; Dubovik et al., 2002; Cattrall et al., 2005). Also, in order to derive the appropriate $S_{\text {aer }}$ values of the vertical backscatter and extinction coefficients it is applied an iterative inversion approach by tuning the $S_{\text {aer }}$ with the AOT values retrieved by the CIMEL data, compare it with those extracted from the LIDAR data:

$\mathrm{AOT}_{\text {LIDAR }}=K \times \mathrm{AOT}_{\mathrm{CIMEL}}=\sum_{0}^{Z_{\text {ref }}} \alpha_{\mathrm{LIDAR}}(r) \Delta r$

where $K$ is a number between 0 and 1 , which might work as a "weight" factor due the fact that the LIDAR overlap is maximum at $300 \mathrm{~m}$ and above one might expect that the portion below might not have been taken into account when estimating the aerosol load contribution to the total AOT (Landulfo et al., 2003). Here $\Delta r$ corresponds to the resolution binning used to calculate the $\alpha$ and $\beta$ the values taken in the whole period show that the maximum AOT values obtained by CATT-BRAMS and measured by the sunphotometer show some large differences which can be understood from three aspects a) the sunphotometer data taken is level 1.5 and the level 2.0 after calibration could change the AOT values due instrument issues; b) The week during the measurements presented some clouds which are taken into account in the model and c) The grid resolution employed in the model gives an average over an area of $40 \times 40 \mathrm{~km}^{2}$. The retrieved coefficients in our case is in a resolution equal to $30 \mathrm{~m}$.

\subsection{Sunphotometer data retrieval}

The inversion of the solar radiances measured by the CIMEL sunphotometer to retrieve the AOT is based on the BeerLambert Law (4), assuming that the contribution of multiple scattering within the small field of view of the sunphotometer is negligible (Holben et al., 1998):

$I_{\lambda}=I_{\lambda}^{o} \exp \left(-\frac{\tau_{\lambda}}{\mu_{s}}\right)$

where $I_{\lambda}$ and $I_{\lambda}^{o}$ are the solar irradiances at the top of the atmosphere and at ground level, respectively, and $\mu_{s}$ is the 

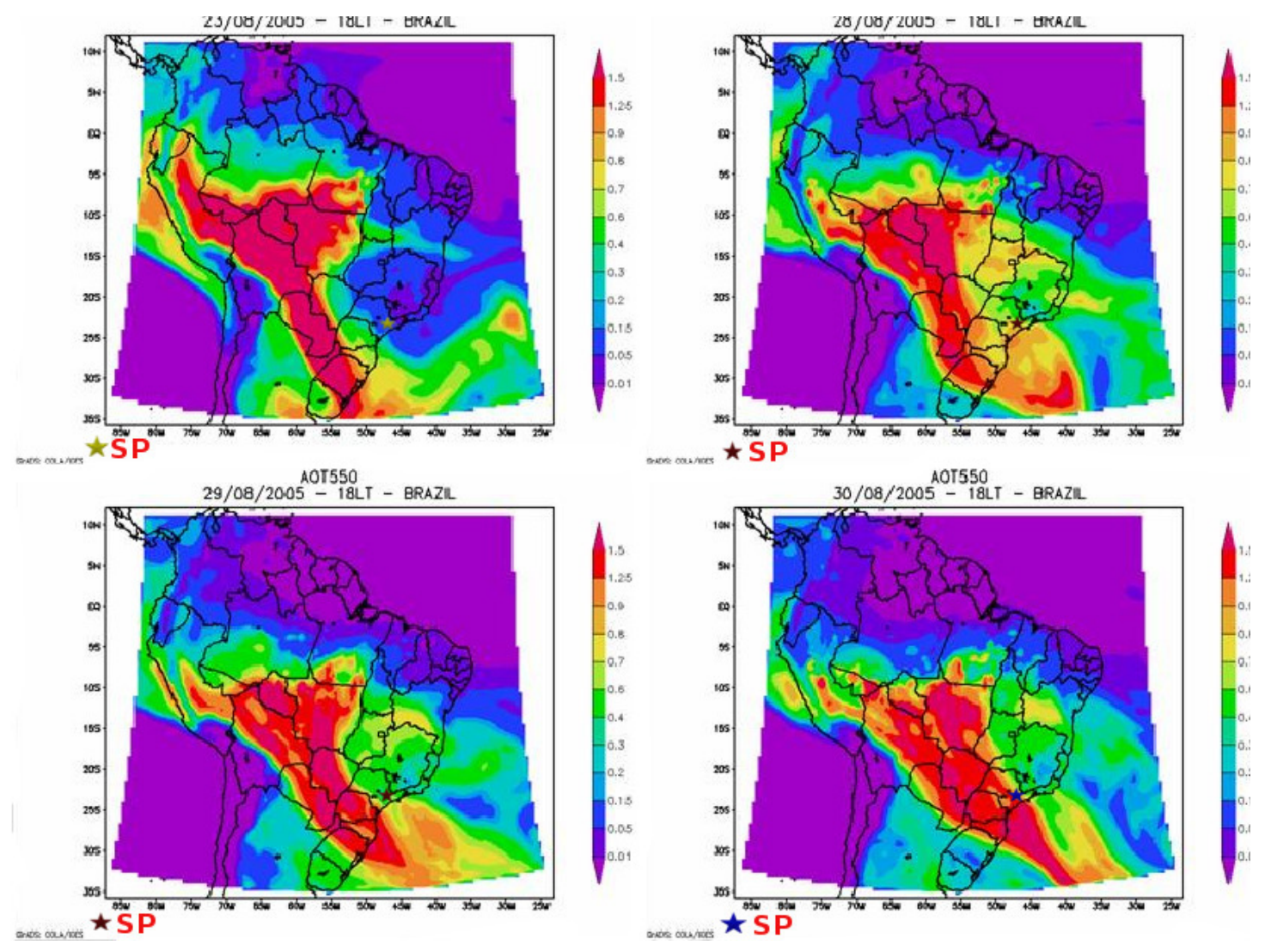

Fig. 1. CATT-BRAMS simulation of AOT at $550 \mathrm{~nm}$ for 23, 28, 29 and 30 August over the Brazilian territory and bordering countries. The star markers gives the São Paulo position in South America.

cosine of the solar zenith angle. $\tau_{\lambda}$ is the total optical thickness from the Rayleigh and aerosol contributions, as well the ozone and water vapour absorption at $670 \mathrm{~nm}$ and $870 \mathrm{~nm}$, respecively. The molecular (Rayleigh) scattering contribution is taken into account to get the aerosol optical thickness values at $532 \mathrm{~nm}$, determined by the relation:

$\frac{\tau_{532}^{\mathrm{aer}}}{\tau_{500}^{\mathrm{aer}}}=\left(\frac{532}{500}\right)^{-\mathrm{a}}$

where, the Angström exponent, å was derived from the measured optical thicknesses in the blue and red channels (440 $\mathrm{nm}$ and $670 \mathrm{~nm}$ ):

$\stackrel{\circ}{=}=-\frac{\log \left(\tau_{440}^{\mathrm{aer}} / \tau_{670}^{\mathrm{aer}}\right)}{\log (440 / 670)}$

In general, the Ångström exponent provides information on the aerosol size distribution, and according to the literature (Dubovik et al., 2002) different types might bear different ranges for the Angström exponent: 1.2 to 2.5 (urbancontinental aerosols; 1.2 to 2.3 (biomass burning); 0 to 1.6 and 0.9 (desert dust and oceanic). The data are retrieved from the AERONET site and given in three data quality levels: Level 1.0 (unscreened), Level 1.5 (cloud-screened) (Smirnov et al., 2005), and Level 2.0 (cloud-screened and quality-assured).

\subsubsection{Results}

The CATT-BRAMS simulations have been very useful in assessing the dispersion and transport of biomass burning aerosol over South America. The period of forest fires spans from late July through early October (Prins et al., 1995) which might vary due meteorological conditions. In this work we made comparisons of some of the CATT-BRAMS products, namely AOT $(550 \mathrm{~nm})$ and $\mathrm{PM}_{2.5}$ over the continent and in special in São Paulo, where a backscattering Lidar system and a AERONET sunphotometer are established. A period of 7 days in late August 2005 (23 August through 30 August) was chosen as case study to observe the model predictions and how the aerosol distribution and impact over the atmospheric optical properties varied during this period. From the CATT-BRAMS simulations, AOT $(550 \mathrm{~nm})$ is obtained every $3 \mathrm{~h}$, starting from 09:00 a.m. (Local Time) to 06:00p.m. Figure 1 illustrates the AOT over the continent for 23, 28, 29 and 30 August (results for the entire period are 


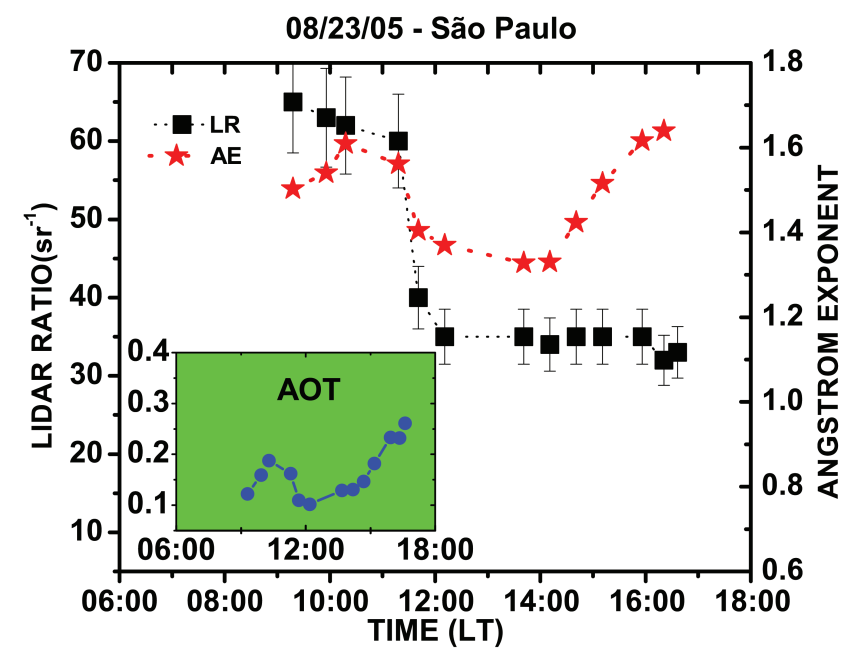

Fig. 2. AOT, AE from CIMEL sunphometer and Lidar-Ratio for 23 August at $532 \mathrm{~nm}$ over the city of São Paulo, the AOT and AE were extracted from the sunphotometer and the Lidar-Ratio was retrieved using the Lidar system at IPEN. The features shown in each panel reveal the aerosol micro-physical patterns with and without the biomass burning aerosol influence. The most evident is the increase in the AOT while the other parameters are related to local sources as well.

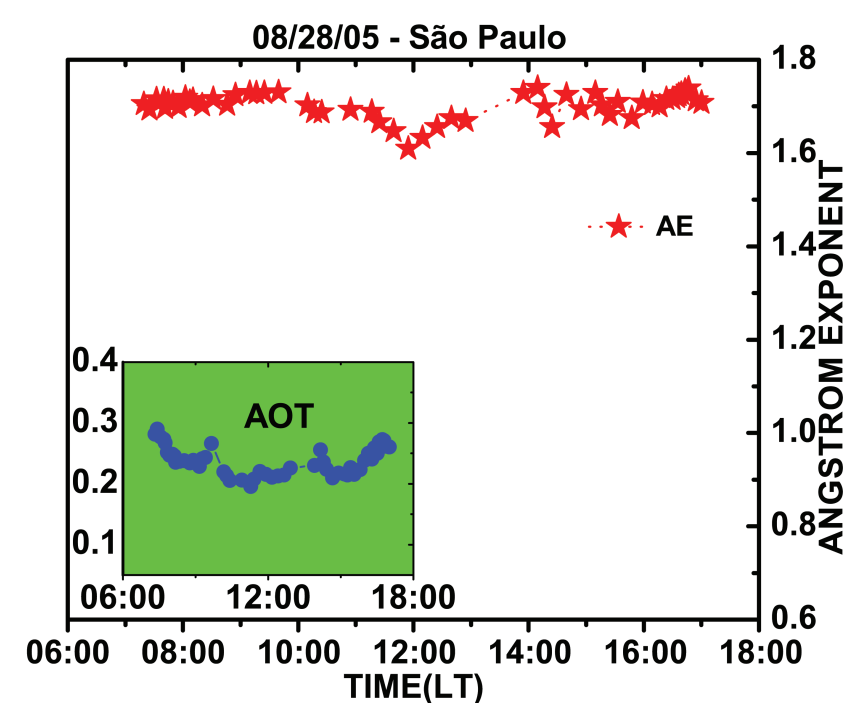

Fig. 3. Same as Fig. 2 for 28 August.

presented in the supplementary material). In August 2005 the frequency of precipitation was higher in the eastern part of north-east Brazil than in the other parts of Amazonia. This increase was associated with the intensification of the trade winds that brought stratiform clouds from the Atlantic Ocean. In the eastern part of southern Brazil the precipitation during the same period was associated with cyclogenesis in the adjoining Atlantic. Although the temperatures were above normal in most parts of the country, two intense cold

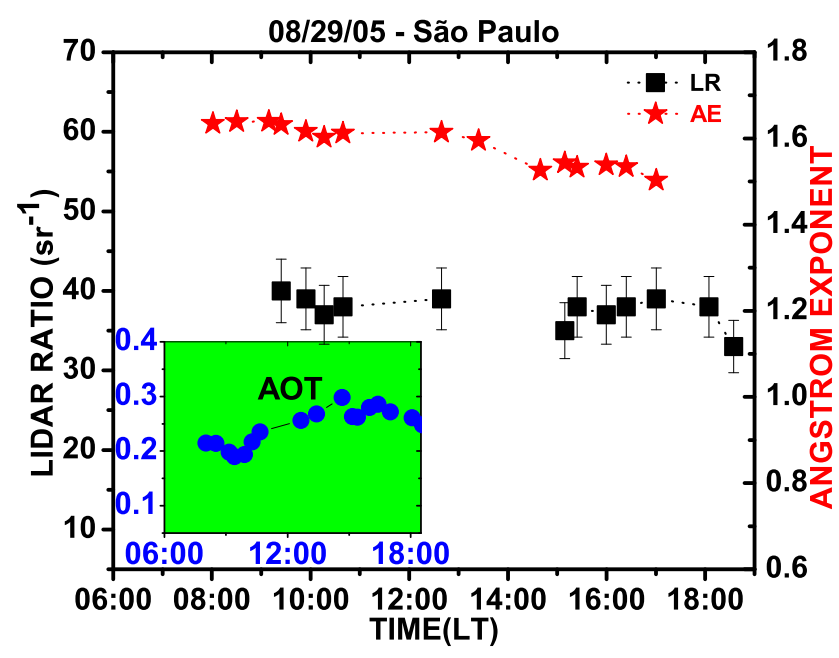

Fig. 4. Same as Fig. 2 for 29 August.

mass penetrations caused steep falls of temperature in the southern and the western regions of Brazil. Six mid-latitude cold fronts from the South Polar Region, associated with low pressure systems, propagated across the South American territory reaching São Paulo metropolitan area. On $23 \mathrm{Au}-$ gust, the fifth cold front developed from a cyclogenesis over Paraguai, Argentina Uruguai and south of Brazil. On the next day, this system moved North passing over São Paulo and reaching Rio de Janeiro state. The last cold front took place on 28 and 29 August over Rio Grande do Sul and then moved northward reaching São Paulo on 31 August. This synoptic conditions created conditions for the spreading of biomass material almost over the western part of the brazilian territory and cold fronts brought these air masses towards the southeastern states where the city of São Paulo is included. This procedure not only permitted us to compare the simulations but also to assess how an influx of biomass burning aerosol could "perturb" the local conditions in a heavy polluted urban area as São Paulo. Biomass burning has a strong impact on simulated AOT (Fig. 1); southward transport of the smoke also affects AOT in mid-west Brazil, Paraguay and Northeastern Argentina. São Paulo remains not affected until 27 August, when a cold front (common in this time of the year) brought aerosol into the city. It is observed then that on 28 August there is a new cold front forming in the south of the continent where a lot of aerosol concentration is observed. Later in this period its advance culminates on $30 \mathrm{Au}-$ gust when AOT values over 1.5 are observed in the region of São Paulo. Tracking these observations we took from the LIDAR system and AERONET the measurements in these days by extracting the AOT, AE and Lidar Ratio variations at $532 \mathrm{~nm}$ over this period which are presented in a form of panel in Figs. 2, 3, 4 and 5, the information is summarized in Table 1. The values taken in the whole period show that the maximum AOT values obtained by CATT-BRAMS and 


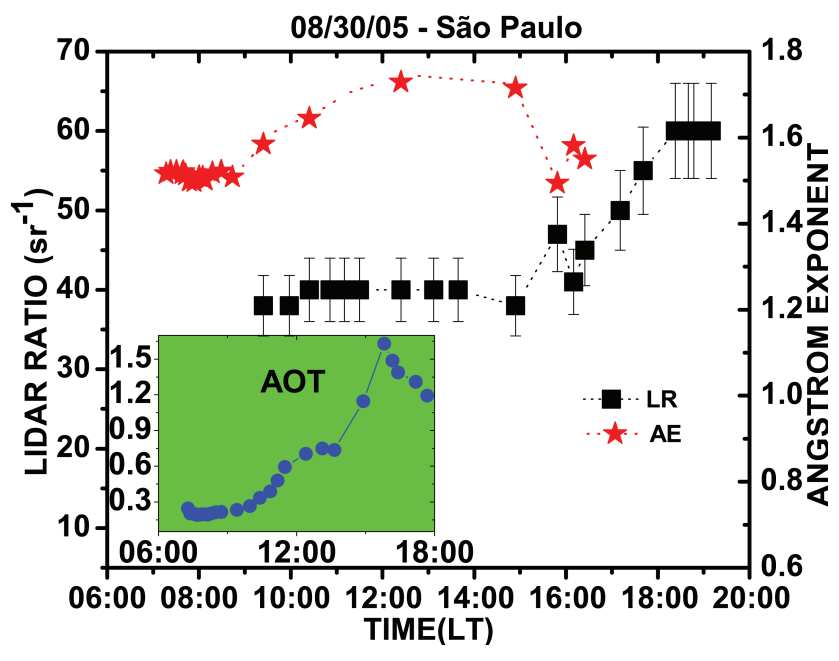

Fig. 5. Same as Fig. 2 for 30 August.

measured by the sunphotometer show some large differences which can be understood as mentioned before from three aspects (a) the SUNPHOTOMETER data taken is level 1.5 and the level 2.0 after calibration can change somehow the AOT; (b) the week during the measurements presented some clouds which are taken into account in the model and (c) the grid resolution employed in the model gives an average over an area of $40 \times 40 \mathrm{~km}^{2}$. A correlation plot, see Fig. 6, was made between the two parameters, AOT BRAMS vs AOT CIMEL, and a $R^{2} \approx 0.47$ was found. Another model feature is worth mentioning is that the AOT is obtained by the spatial averaging over a grid that covers the city of São Paulo. One might see that on days 23 and 30 when the presence of biomass burning transported from remote areas is predicted one observes a steep increase in the AOT, and the largest variations in the AE and LR parameters. As expected the high values of LR are a signature of strong absorbing particles (Anderson et al., 2000) and since due transport over a large distance one expects increases in size as result of coagulation, condensation and gas-to-particle conversion (Reid et al., 1998) therefore size distributions can present both coarse and fine modes in equal amounts. Besides the vertical lidar profiles taken during this period one could detect that the incoming air parcels bringing aerosols were about $3-4 \mathrm{~km}$ discarding the possibility the aerosol load was only from local sources. The model also generated the $\mathrm{PM}_{2.5}$ concentration product shown in Fig. 7 where it can be clearly seen a strong correlation between the particle concentration and AOT values for a period of almost ten days beginning on 24 August. That was expected since the coarse mode particles are more prone to be deposited nearby the source and would have a shorter residence time in the atmosphere.

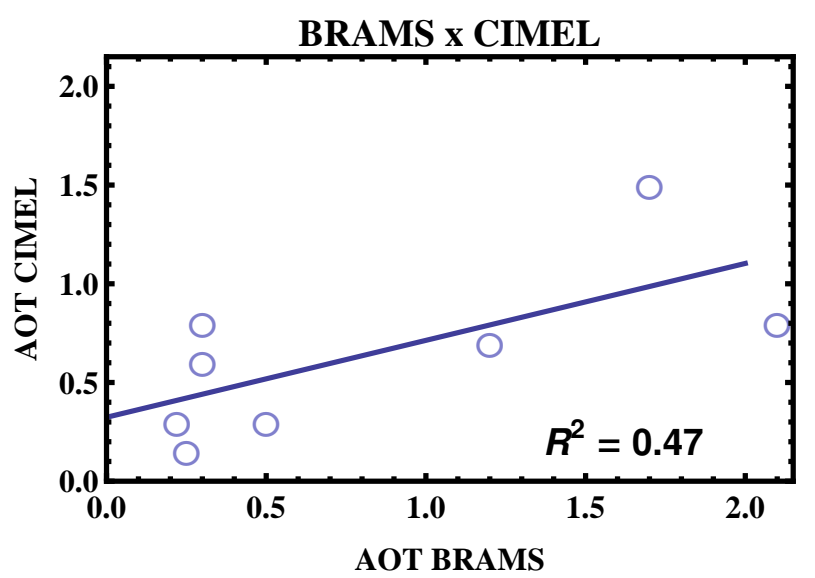

Fig. 6. A correlation plot between the BRAMS retrieved AOT and the measured by the AERONET sunphotometer (CIMEL).

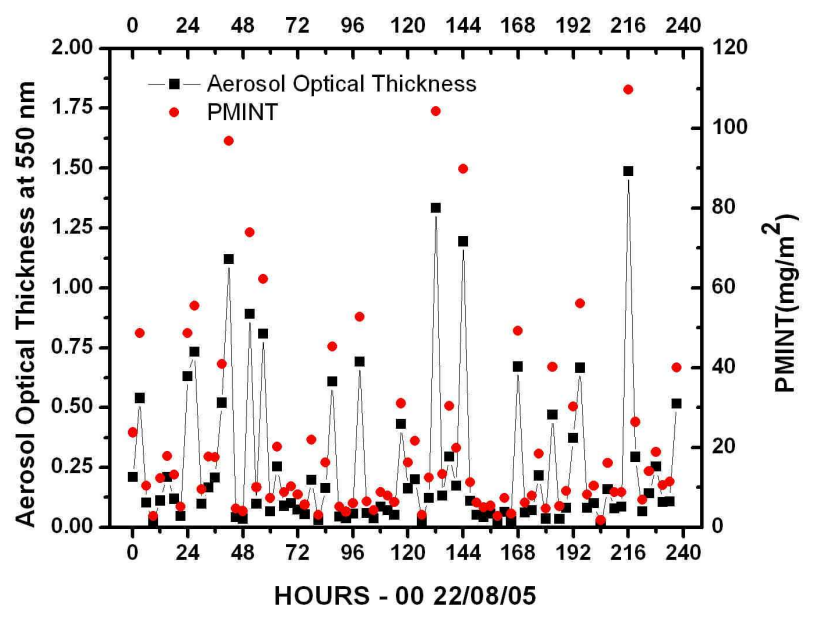

Fig. 7. AOT from CIMEL sunphotometer at $550 \mathrm{~nm}$ and $\mathrm{PM}_{2.5}$ column integrated concentration during a period of ten days starting on 22 August 2005. There is a direct correlation between these two quantities and the largest values were observed when intense biomass burning aerosol transport took place over the Metropolitan Region of São Paulo.

\section{Conclusions}

We have performed a comparison study of aerosol optical thickness (AOT) from numerical simulations using a regional atmospheric model with an elastic backscattering lidar operating at $532 \mathrm{~nm}$ and a sunphotometer belonging to the AERONET network at São Paulo $\left(23^{\circ} \mathrm{S} 46^{\circ} \mathrm{W}\right)$ city, Brazil. This synergy proved to be very fruitful in understanding local and regional aerosol transport and its presence at many different layers and also helped qualitatively in deriving and interpreting the AOT, the AE and the extinction-to-backscattering ratio values, important microphysical quantities to describe 
Table 1. Summarized data of the period of our study with the main quantities retrieved by the intrumentation and calculated by CATTBRAMS. The values taken in the whole period show that the maximum AOT values obtained by CATT-BRAMS and measured by the sunphotometer show some large differences which can be understood from three aspects (a) the sunphotometer data taken is level 1.5 and the level 2.0 after calibration can change somehow the AOT; (b) the week during the measurements presented some clouds which are taken into account in the model and (c) the grid resolution employed in the model gives an average over an area of $40 / 40 \mathrm{~km}$.

\begin{tabular}{rrrrr}
\hline mm-dd-yy & $\begin{array}{r}\text { MAX AOT } \\
\text { Observed }\end{array}$ & $\begin{array}{r}\text { MAX AOT } \\
\text { (BRAMS) }\end{array}$ & AE variation & LR variation \\
\hline $08-23-05$ & 0.25 & $\sim 0.15$ & $1.48-1.67$ & $33-65$ \\
$08-24-05$ & 0.50 & $\sim 0.30$ & $0.49-0.98$ & $30-33$ \\
$08-25-05$ & 0.22 & $\sim 0.30$ & 1.42 & N/A \\
$08-26-05$ & 1.20 & $\sim 0.70$ & $1.25-1.53$ & $46-55$ \\
$08-27-05$ & 2.10 & $\sim 0.80$ & 1.45 & N/A \\
$08-28-05$ & 0.30 & $\sim 0.80$ & $1.60-1.75$ & N/A \\
$08-29-05$ & 0.30 & $\sim 0.60$ & $1.50-1.60$ & $33-40$ \\
$08-30-05$ & 1.70 & $>1.50$ & $1.55-1.75$ & $39-60$ \\
\hline
\end{tabular}

the aerosol optical properties. Predictions carried out with the CATT-BRAMS model were found to be in agreement with observations; the model was able to reasonably capture the effects of long-range transport of biomass burning smoke on AOT. The strong temporal correlation between simulated and measured AOT on RMSP (Fig. 7) suggests that the time variability of AOT at São Paulo are not only explained by the local aerosol sources and atmospheric dynamics, but also are influenced by long-range transport of smoke. There are instances where predictions do not agree with observations and could be related to several issues. For example, measurements may not always represent properties at the model-resolved spatial scale; discrepancies can also arise from errors in emission inventories, simulated relative humidity, cloud fields and model dynamics.

Nevertheless, the synoptical description gave a good background in comprehension of the transport biomass burning aerosol from remote areas such as the central-western and Northern regions into the southern and south-eastern parts of Brazil. Such transport was associated with low pressure systems generated by cold fronts originating in the South Polar latitudes. Further efforts should be taken into extending the time series in other years and comparing with other instruments besides the LIDAR system and sunphotometer employed with emphasis on satellite products from MODIS and/or CALIPSO for instance.

Acknowledgements. The authors would like to thank to FAPESP (Fundação de Amparo À Pesquisa do Estado de São Paulo) and CAPES (Coordenação de Aperfeiçoamento de Pessoal de Nível Superior) for the support of this work. S. R. Freitas acknowledge CNPq (305059/2005-0) for partial support. This work was carried out with the aid of a grant from the Inter-American Institute for Global Change Research (IAI) CRN II 2017 which is supported by the US National Science Foundation (Grant GEO-0452325). The authors are also thankful for the careful and detailed revision work carried out by the reviewers and editor of this paper.

Edited by: A. Nenes

\section{References}

Ackermann, J.: The Extinction-to-Backscatter Ratio of Tropospheric Aerosol: A Numerical Study, J. Atmos. Ocean. Tech., 15, 1043-1050, 1998.

Anderson, T. L., Masonis, S. J., Covert, D. V., Charlson, R. J., and Rood, M. J.: In situ measurement of the aerosol extinciton-tobackscatter ratio at a polluted continental site., J. Geophys. Res., 105, 26907-26915, 2000.

Cattrall, C., Reagan, J., Thome, K., and Dubovik, O.: Variability of aerosol and spectral lidar and backscatter and extinction ratios of key aerosol types derived from selected Aerosol Robotic Network locations, J. Geophys. Res., 110(D10), D10SA11, doi:10.1029/2004JD005124, 2005.

Dubovik, O., Holben, B., Eck, T. F., Smirnov, A., Kaufman, Y. J., King, M. D., Tanré, D., and Slutsker, I.: Variability of Absorption and Optical Properties of Key Aerosol Types Observed in Worldwide Locations, J. Atmos. Sci., 59, 590-608, 2002.

Freitas, S., Longo, K., Silva Dias, M., Silva Dias, P., Chatfield, R., Prins, E., Artaxo, P., Grell, G., and Recuero, F.: Monitoring the transport of biomass burning emissions in South America, Environ. Fluid Mech., 5(1-2), 135-167, doi:10.1007/s10652-0050243-7, 2005.

Freitas, S. R., Longo, K. M., Silva Dias, M. A. F., Chatfield, R., Silva Dias, P., Artaxo, P., Andreae, M. O., Grell, G., Rodrigues, L. F., Fazenda, A., and Panetta, J.: The Coupled Aerosol and Tracer Transport model to the Brazilian developments on the Regional Atmospheric Modeling System (CATT-BRAMS) Part 1: Model description and evaluation, Atmos. Chem. Phys., 9, 28432861, 2009, http://www.atmos-chem-phys.net/9/2843/2009/.

Gevaerd, R. and Freitas, S. R.: Estimativa operacional da umidade do solo para iniciação de modelos de previsão numérica da atmosfera, Parte I: Descrição da metodologia e validação, Revista Brasileira de Meteorologia, 21(3a), 59-73, 2006.

Giglio, L., Descloitres, J., Justice, C. O., and Kaufman, Y. J.: An enhanced contextual fire detection algorithm for MODIS, Remote Sens. Environ., 87, 273-282, 2003.

Holben, B. N., Eck, T. F., Slustker, I., Tanré, D., Buis, D. P., Setzer, A. F., Vermote, E., Reagan, J. A., Kaufman, Y. J., Nakajima, T., 
Lavenu, F., Jankowiak, I., and Smirnov, A.: Aeronet - a federal instrument networkand data archive for aerosol characterization, Remote Sens. Environ., 66, 1-66, 1998.

Klett, J.: Lidar Inversion with variable backscatter/extinction ratios, Appl. Optics, 24, 1638-1643, 1985.

Landulfo, E., Papayannis, A., Artaxo, P., Castanho, A. D. A., de Freitas, A. Z., Souza, R. F., Vieira Junior, N. D., Jorge, M. P. M. P., Sánchez-Ccoyllo, O. R., and Moreira, D. S.: Synergetic measurements of aerosols over São Paulo, Brazil using LIDAR, sunphotometer and satellite data during the dry season, Atmos. Chem. Phys., 3, 1523-1539, 2003,

http://www.atmos-chem-phys.net/3/1523/2003/.

Landulfo, E., Papayannis, A., Freitas, A. Z., Vieira Jr., N. D., Souza, R. F., Gonçalves, A., Castanho, A. D. A., Artaxo, P., SánchezCCoyllo, O. R., Moreira, D. S., and Jorge, M. P. M. P.: Tropospheric aerosol observations in Sao Paulo, Brazil using a compact lidar system, Int. J. Remote Sens., 13, 2797-2816, 2005.

Longo, K. M., Freitas, S. R., Setzer, A., Prins, E., Artaxo, P., and Andreae, M. O.: The Coupled Aerosol and Tracer Transport model to the Brazilian developments on the Regional Atmospheric Modeling System (CATT-BRAMS) - Part 2: Model sensitivity to the biomass burning inventories, Atmos. Chem. Phys. Discuss., 7, 8571-8595, 2007,

http://www.atmos-chem-phys-discuss.net/7/8571/2007/.

Longo, K. M., Freitas, S. R., Dias, M. S., and Dias, P. S.: Numerical modelling of the biomass-burning aerosol direct radiative effects on the thermodynamics structure of the atmosphere and convective precipitation, in: International Conference on Southern Hemisphere Meteorology and Oceanography (ICSHMO),8, edited by: São Josẽ dos Campos, I., 283-289, 2006a.
Longo, K. M., Freitas, S. R., Ulke, A. G., and Hierro, R. F.: Transport of biomass burning products in Southeastern South America and its relationship with the South American Low Level Jet East of the Andes, in: International Conference on Southern Hemisphere Meteorology and Oceanography (ICSHMO), 8, edited by: São José dos Campos, I., 121-129, 2006b.

Prins, E. M., Feltz, J. M., Menzel, W. P., and Ward, W. D.: An Overview of GOES-8 Diurnal Fire and Smoke Results for SCAR-B and 1995 Fire Season in South America., J. Geophys. Res., 103(D24), 31821-31835, 1995.

Reid, J. S., Ferek, R. J., Blake, D. R., Martins, J. V., and Liousse, C.: Physical and Optical properties of regional hazes dominated by smoke in Brazil, J. Geophys. Res., 103, 32059-32080, 1998.

Setzer, A. and Pereira, M.: Amazonia biomass burnings in 1987 and an estimate of their tropospheric emissions, Ambio, 20, 19-22, 1991.

Smirnov, A., Holben, B. N., Eck, T., Dubovik, O., and Slutsker, I.: Cloud screening and quality control algorithms for the AERONET database, Remote Sens. Environ., 73, 337-349, 2005.

Vera, C., Baez, J., Douglas, M., Emmanuel, C. B., Marengo, J., Meitin, J., Nicolini, M., Nogues-Paegle, J., Paegle, J., Penalba, O., Salio, P., Saulo, C., Silva Dias, M. A., Silva Dias, P., and Zipser, E.: The South American Low-Level Jet Experiment, B. Am. Meteorol. Soc., 87, 63-77, 2006.

Walko, R., Band, L., Baron, J., Kittel, F., Lammers, R., Lee, T., Ojima, D., Pielke, R., Taylor, C., Tague, C., Tremback, C., and Vidale, P.: Coupled Atmosphere-Biophysics-Hydrology Models for Environmental Modeling., J. Appl. Meteorol., 39(6), 931944, 2000. 